\title{
$\mathrm{SMATV}$ 를 위한 MATV/위성 방송 통합형 증폭기 개발에 관한 연구 \\ 이진영 $1^{*}$ \\ ${ }^{1}$ 강남대학교 교양학부
}

\section{Development of an integrated amplifier for MATV/Satellite Broadcasting}

\author{
Jin-Young Lee ${ }^{1^{*}}$ \\ ${ }^{1}$ Department of Liberal Arts, Kangnam University
}

\begin{abstract}
요 약 최근 국내에서는 MATV(Master Antenna Television:텔레비전 공동시청 설비)를 SMATV(Satellite Master Antenna Television)로 개정함에 따라 공동주택의 방송설비는 지상파 방송, FM 라디오 방송과 함께 위성방송을 의무 적으로 통합하여 전송하도록 개정하였다. 국외의 경우 대부분의 나라에서 SMATV가 기본적으로 허용된데 반해 국내 에서는 케이블 방송과 위성방송 서비스 업체간의 이익 분쟁으로 인해 SMATV용 혼합형 증폭기에 대한 기술 개발 및 양산이 미진한 상태에 있다. 따라서, 본 연구에서는 지상파 텔레비전 방송대역(54 806Mhz)과 FM 라디오 방송대역 (88 108Mhz) 뿐만 아니라 위성방송 대역(950 2150Mhz)까지 증폭할 수 있는 광대역 증폭기를 개발하고 그에 따른 문 제점의 해결방안을 제시한다.
\end{abstract}

\begin{abstract}
Recently $\mathrm{n}$ Korea, the House of Commons and terrestrial broadcasting facilities integrated with FM radio and the satellite compulsory was amended to transfer MATV(Master Antenna Television) adjusted by SMATV(Satellite Master Antenna Television). While the SMATV was accepted by default in most other countries, our county did not accept it as the default for broadcast. Because domestic cable and satellite television service providers are conflicts with their interest. bAs a result, the hybrid amplifier for SMATV technology development and volume production for the state is insufficient. Therefore, terrestrial television broadcast bands $(54 \sim 806 \mathrm{Mhz})$ and FM radio broadcast band $(88 \sim 108 \mathrm{Mhz})$ band satellite with $(950 \sim$ $2150 \mathrm{Mhz})$ to amplify the development of a broadband amplifier with subsequent resolution of problems is also presented in this study.
\end{abstract}

Key Words : Broadcast convergence, MATV, SMATV, Satellite broadcast, Amplifier

\section{1. 서론}

국내의 MATV 관련기술은 SMATV 설비기준으로 개 정되기 전의 규정에 맞추어 위성방송을 제외한 지상파 방송과 FM 라디오 방송만을 전송할 수 있는 시스템 기술 개발에 주력해 왔다. 국외의 대다수 나라에서는 SMATV 가 기본적으로 허용되어 시청자의 볼 권리 보장 및 디지 털 방송 전환에 촉진제 역할을 하고 있다. 반면 국내의 경우에는 케이블 방송과 위성방송 서비스 업체간의 이익
분쟁으로 인하여 2007년 11월에 개정되어 발표되었다[1]. 따라서, 국내의 경우 SMATV용 혼합형 증폭기 시장은 법규 개정이전에 특수한 목적으로만 사용되었기 때문에 기술개발이 활발하지 못하였다.

ITU(International Telecommunication Union ; 국제전 기통신연합)는 위성방송 수신방법으로 '개별수신' 과 ‘공 동수신’을 규정(ITU RRS1.39)하고 있는데 ‘개별수신'이 라함은 일반적으로 가구별로 위성 안테나를 설치하여 방 송을 시청하는 형태이고, '공동수신'은 하나의 위성 안테

본 논문은 강남대학교 연구과제로 수행되었음.

"교신저자 : 이진영(goodman3@kangnam.ac.kr)

접수일 10 년 11 월 18 일 수정일 10 년 12 월 01 일 게재확정일 10 년 12 월 17 일 
나를 이용하여 여러 가구가 동시에 시청하는 것으로 규 정하고 있다[2]. 국내와 달리 세계 대부분의 국가에서는 SMATV를 허용하여 왔으며, 이에 따른 기술개발이 활발 히 이루어져 왔다. 하지만 국가 및 지역별로 주파수 대역 과 사용방식에 차이가 있기 때문에 상호적용시 제품수정 이 불가피하다. 따라서, 본 연구에서는 공동주택의 각 세 대까지 연결되는 동축선로를 통하여 지상파 텔레비전 방 송대역(54 806Mhz)과 FM 라디오 방송 대역 (88 108Mhz)과 함께 위성방송 대역(950 2150Mhz)을 증 폭할 수 있는 광대역 증폭기를 제안한다.

그러나, 이와같은 증폭기 방식은 방송 서비스별로 변 조 방식이 다르기 때문에 서비스 대역을 제외한 대역에 예상치 못한 노이즈가 발생된다. 따라서, 제안된 SMATV 는 하나의 동축선로에 MATV 방송 및 위성방송을 결합 하여 전송하는 방식이기 때문에 예상치 못한 노이즈가 발생하게 되고 이는 다른 방송 서비스 대역에 영향을 주 어 방송품질에 저하를 유발하는 문제점을 안고 있다 [3][4]. 본 논문에서는 이에 대한 해결방안으로 서비스별 증폭대역을 분리하여 증폭하고 이를 다시 결합하여 전송 하는 방식을 제안하고 이에 따른 부가적인 문제점들에 대한 해결방안을 제시한다.

\section{2. 연구내용 및 개발 방법}

\section{1 연구 내용}

본 연구에서는 SMATV 설비기준에 부합되도록 MATV 및 위성방송 대역이 전송 가능한 증폭기를 개발 하는 것으로 목표로 한다. 아울러 각 방송 서비스간의 간 섭을 최소화하여 고품질의 서비스가 가능함과 동시에 동 축 전송선로에서 발생되는 대역별 신호 기울기를 보정하 고, 사용자가 설치 및 조정이 용이한 시스템 개발을 연구 범위로 한다.

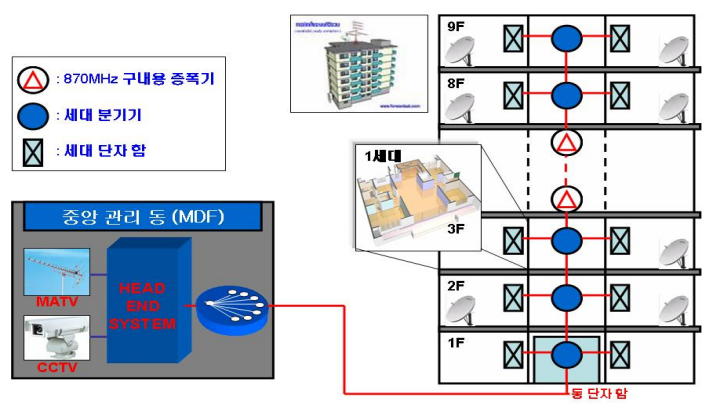

[그림 1] 기존 MATV 방송설비 구성도
기존의 MATV 방송설비 구성도는 그림 1과 같으며 공 동주택의 중앙관리동(MDF실)내의 헤드엔드 시스템 (HEAD-END System)을 통해 처리된 방송신호를 분배하 여 각 공동주택내의 각 세대로 전송하는 구조로 설비되 어 있다. 위성방송의 경우에는 각 세대의 위성수신이 가 능한 외벽에 위성 안테나를 따로 설치하여 방송을 시청 하는 형태로 구성되어 있다. 따라서, 아파트 미관문제와 설치시 안전에 대한 문제점과 저층의 경우 위성수신에 제약을 받아 위성방송수신이 불가능한 사각지역이 발생 하는 문제점이 있다.

개정된 SMATV 방송설비 구성도는 그림 2와 같다. 공 동주택내의 중앙관리동(MDF실)이나 공공주택 건물옥상 등에 위성 안테나를 설치하여 기존 MATV 설비를 통해 전송하는 구조로 되어있다. 각 세대별로 위성안테나를 설 치할 필요가 없어 자원낭비 및 중복투자 문제가 해소된 다[5,6]. SMATV 구조는 MATV 설비에 통합형 구내용 증폭기 장치만을 설비·변경하여 간단하게 구성할 수 있기 때문에 기존에 공동주택에도 쉽게 변경·적용이 가능하다. 그러나, 기존 공동주택 경우 증폭기가 설치되는 공간에 제약이 따르므로 통합형 구내용 증폭기의 개발이 필요하 다.

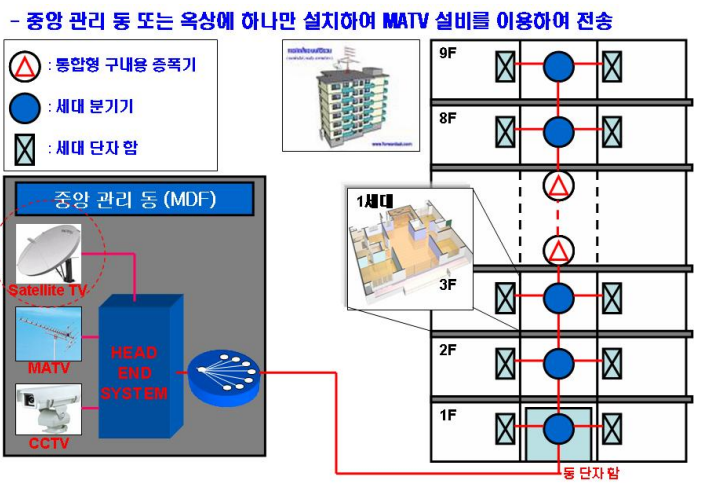

[그림 2] 개정된 SMATV 방송설비 구성도

\section{2 개발 방법 및 기술}

본 연구에서 개발된 SMATV용 MATV/위성방송 통합 형 구내용 증폭기의 구조는 그림 3 과 같다. 통합형 구내 용 증폭기는 하나의 RF 입력단자와 하나의 RF 출력단자 로 구성된다. 


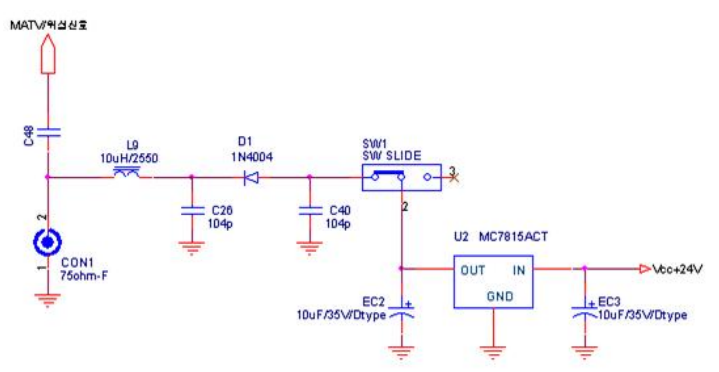

[그림 3] 통합형 구내용 증폭기 구조

입력단자인 MATV / Satellite INPUT Port는 MATV와 위성방송대역을 동시에 수용할 수 있으며 출력단자인 MATV/Satellite OUTPUT Port는 증폭된 두 방송신호를 결합하여 동시에 출력되는 단자이다. 각 부분별 기능과 적용 기술 내용은 다음과 같다.

\subsection{1 전원 삽입기(Power Insert) 기술}

입력되는 신호의 임피던스 및 주파수 응답에 변화가 없도록 하기 위해 신호입력 포트에 $10 \mathrm{uH}$ 이상의 높은 인 턱터를 적용하여 $\mathrm{LNB}$ 에 전원을 공급할 수 있도록 설계 하였다. 또한 $\mathrm{LNB}$ 에 충분한 전력을 공급하기 위해 $15 \mathrm{VDC}$ 에서 $3 \mathrm{~A}$ 이상의 부하를 견딜 수 있는 인턱터를 적 용하였다. 부하량이 적을 경우 케이블 및 $\mathrm{LNB}$ 에 부하량 을 견딜 수 없어 전원공급에 문제가 발생될 수 있다. $\mathrm{AC}$ 커플링을 통해 $\mathrm{DC}$ 전원이 증폭기 내부로 유입되는 것을 차단하였다. 본 연구에서는 그림 5 와 같이 회로를 설계하 여 전원 삽입기를 적용하였다. 또한 $\mathrm{ON} / \mathrm{OFF}$ 스위치를 적용하여 선택적으로 전원을 공급 또는 차단할 수 있도 록 하였다.

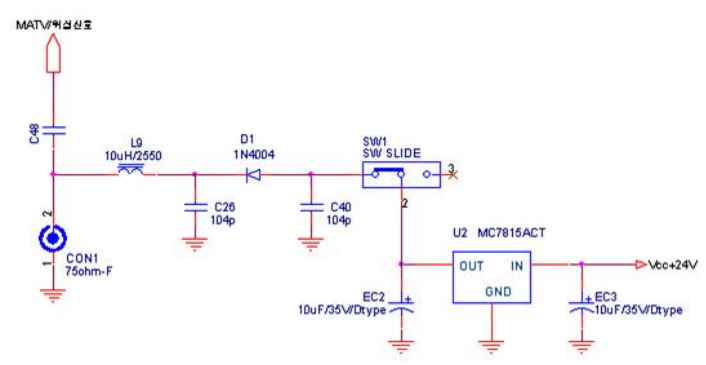

[그림 4] 전원 삽입기 회로

\subsubsection{MATV 대역과 위성대역을 분리 또는 결합 하는 Diplexer Filter 기술}

상기 기술개발은 증폭기로 입력되는 결합된 MATV 대역신호와 위성 대역신호를 분리하고, 분리된 신호가 대
역별 증폭장치를 통해 증폭한 후 다시 결합하기 위해 필 요하다. 본 기술은 서로 다른 두 대역을 분리하여 대역별 로 증폭함으로서 증폭도를 높이고 각 대역의 전송이득 및 전송등화특성을 조절할 수 있어 서비스별 성능을 최 적화 할 수 있다. 또한, 각 대역에서 발생되는 간섭성분을 제거하여 결합시킴으로서 결과적으로 두 서비스간에 최 대한 영향을 끼치지 않고 증폭이 가능하다. 본 연구에서 는 그림 5의 회로도와 같이 High Pass Filter와 Low Pass Filter를 결합한 형태의 Diplexer Filter를 제안하며 시뮬레 이션은 그림 6 과 같다.

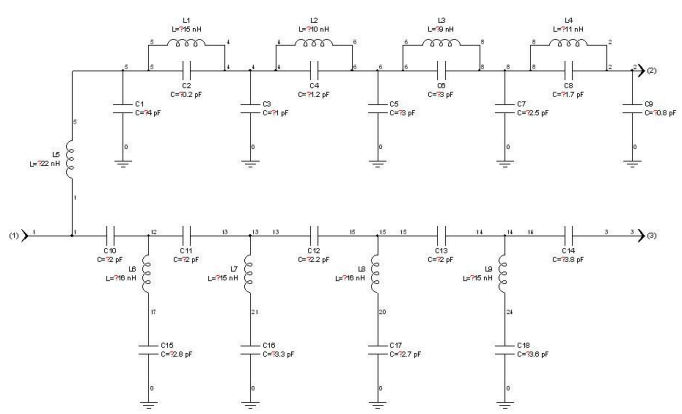

[그림 5] Diplexer filter 회로도

그림 6의 시뮬레이션 결과 MATV 주파수응답(S21)과 위성대역의 주파수응답(S31) 모두 안정적인 응답 곡선을 보여주며 $20 \mathrm{~dB}$ 이상의 분리도를 보여준다. 반사손실 (S11) 또한 $-20 \mathrm{~dB}$ 이하로 우수한 특성으로 시뮬레이션 결 과를 얻었다. 높은 분리도는 대역 간에 발생되는 간섭을 억제시키고 서비스대역을 통해 발생되는 대역 외 스퓨리 어스(Spurious) 성분을 분리 또는 결합시 제거할 수 있다.

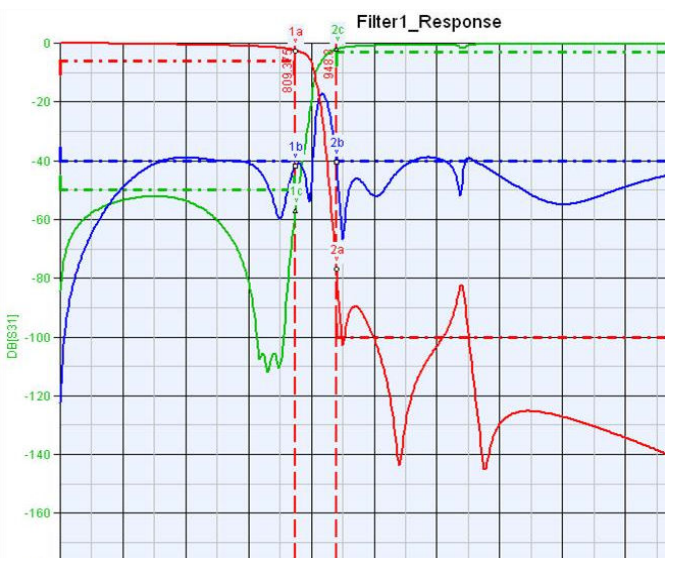

[그림 6] Diplexer filter 시뮬레이션 결과 


\subsection{3 상향 노이즈 및 전원 노이즈 제거기능을 갖 는 High Pass Filter 기술}

상기 Diplexer Filter의 경우 MATV 대역에 있어 Low Pass Filter 기능을 가지므로 $806 \mathrm{Mhz}$ 이하의 대역을 전부 통과시킨다. 문제는 동축전송로 상에서 발생되는 상향노 이즈가 그대로 유입될 수 있어 증폭기 성능을 저하시키 는 원인이 되며 전원 스위칭 노이즈 또한 유입될 가능성 이 있다. 따라서, 본 연구에서는 MATV 대역만을 통과시 키도록 54MHz High Pass Filter를 제안 개발하였다.

그림 7과 그림 8은 $54 \mathrm{MHz}$ High Pass Filter의 회로도 와 시뮬레이션 결과이다.

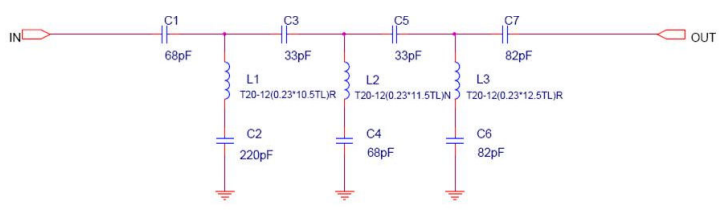

[그림 7] 54MHz High pass filter

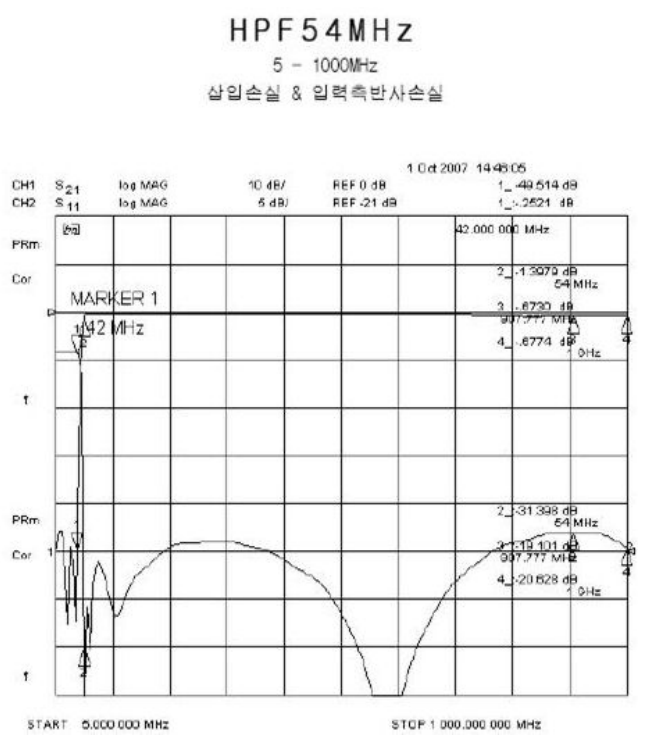

[그림 8] $54 \mathrm{MHz}$ High pass filter 시뮬레이션 결과

\subsection{4 조절형 광대역 RF 감쇠기(Adjustable RF Attenuator) 기술}

광 대역 감쇠기는 대역별 $\mathrm{RF}$ 출력이득을 조정하는 기 능을 담당하며, 이득 조정을 통하여 동축선로에서 발생되 는 손실을 보상하고 다음 단에 위치한 증폭기의 입력레 벨을 조절하여 선로 상에 발생되는 선형성을 최대한 유 지할 수 있도록 해준다. 또한, 사용자 종단장치인 TV나
셋톱박스장치들에 적정입력조건을 맞추는 기능을 담당하 기도 한다.

입력되는 RF 신호는 케이블 거리나 상태에 따라 전송 손실에 차이가 발생할 수 있는데 이는 증폭소자에서 발 생될 수 있는 과입력에 따른 RF 포화(Saturation)현상이 발생될 수 있기 때문이다. 이와같은 문제는 MATV방송 대역 및 위성방송대역의 레벨을 조정할 수 있는 RF 감쇠 기를 이용하여 입력변화에 따른 방송레벨을 설치장소에 따라 조절함으로서 문제를 해결할 수 있다. 따라서, 본 연 구에서는 MATV 대역은 수동형 RF 감쇠모듈을 적용하 여 설계하고, 위성방송대역의 경우 WideBand용 PIN 다 이오드를 이용하여 전압 감쇠기(Voltage Attenuator)를 설 계하여 조절형 광대역 $\mathrm{RF}$ 감쇠기를 개발하였다.

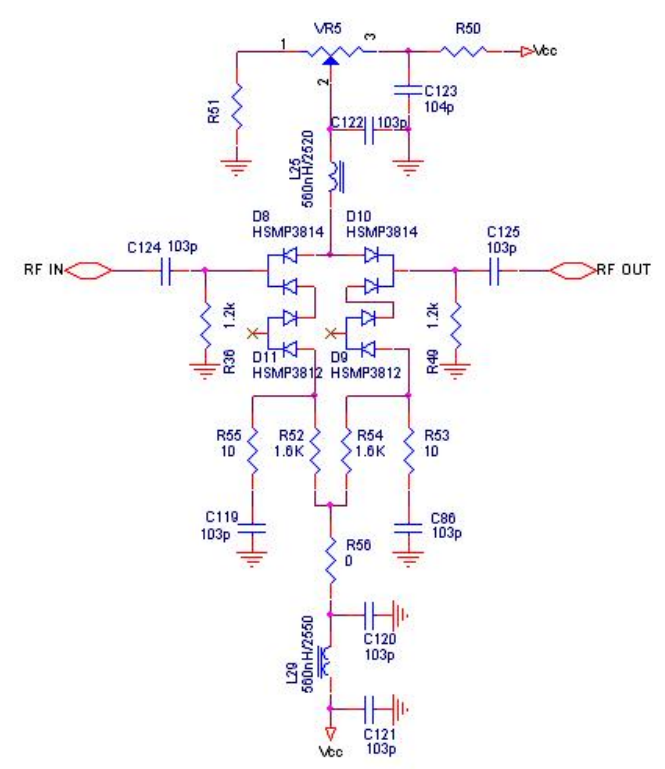

[그림 9] 위성방송대역 조절형 광대역 RF 감쇠기

그림 9는 위성대역의 조절형 광대역 RF 감쇠기 회로 이다. 위성대역의 경우 높은 주파수 대역과 넓은 대역전 송 때문에 MATV와 같은 감쇠기모듈이 상용화되지 못하 고 있는데 본 연구에서는 고주파 PIN Diode의 전류특성 을 이용하여 삽입손실을 조절할 수 있는 감쇠기 회로를 설계하여 위성대역에 대하여 $10 \mathrm{~dB}$ 이득을 조절할 수 있 도록 하였다.

\subsubsection{Adjustable RF SLOPE(조절형 신호 기울 기 조정) 기술}

신호의 감쇠는 전달 Cable이나 부하기를 거치면서 생 긴다. 이 때 낮은 주파수보다 높은 주파수가 비례적으로 
감쇠량이 증가하여 그림 10 의 (a)와 같이 주파수별로 다 른 감쇠가 나타나 신호기울기로 나타난다. 상기 신호 기 울기는 방송채널별로 방송품질 고르지 못하게 하는 주된 원인이 되고, 이를 보정하기 위하여 등화기(Equalizer)를 설계·적용하였다. 본 연구에서는 그림 10 과 같이 전달경 로상에서 발생된 신호의 기울기와 반대되는 기울기를 만 들어 신호의 감쇠를 균등하게 보정할 수 있도록 하였다. 또한 SLOPE 모듈은 공동주택의 동축선로에서 발생될 수 있는 $6 \mathrm{~dB}$ 이상의 신호기울기를 조정할 수 있다.

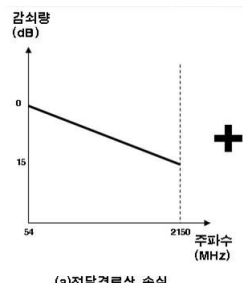

(a)전달경로상 손실

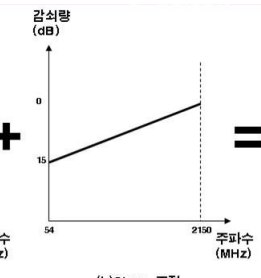

(b)Slope 조점

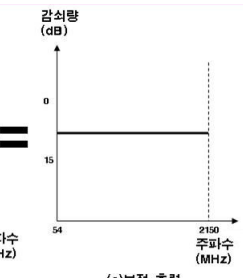

(c)보정 훌려
[그림 10] 신호 기울기의 조정원리

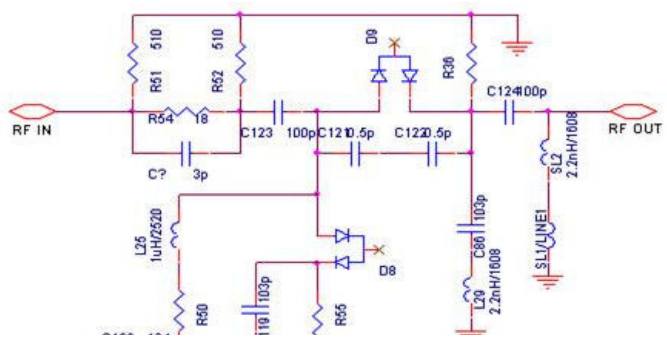

[그림 11] MATV 등화기 회로도

설계된 등화기는 MATV용과 위성대역용으로 구분하 여 설계하였으며 그림 11은 MATV용 등화기 회로도로 $\mathrm{RF}$ 감쇠기 모듈을 적용하여 대역별로 감쇠손실을 달리하 여 기울기가 발생하도록 하였다.

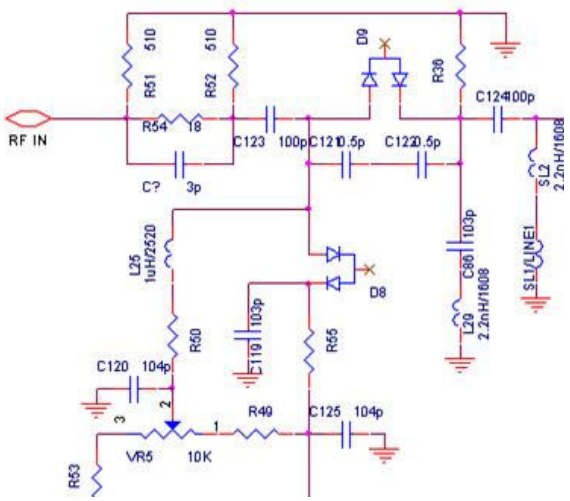

[그림 12] 위성대역용 등화기 회로도
그림 12는 위성대역용 등화기 회로로 PIN Diode의 감소기능을 이용하여 대역별 손실값을 달리하여 조절할 수 있도록 하였다.

\subsubsection{AMP(신호증폭기) 기술}

$\mathrm{AMP}$ 는 신호를 증폭하는 기능을 담당하는 장치로 본 연구에서 가장 핵심 장치로 선형성이 우수한 증폭소자를 적용하고, 증폭소자에서 발생되는 소비열을 방출할 수 있 도록 기구적인 특성을 고려한다. 또한 높은 증폭에 따른 피드백 성분 노이즈의 유입을 제거하기 위하여 차폐 및 설계위치 등에 대한 고려도 함께 이루어져야 한다.

MATV 증폭단 설계를 위해서는 푸쉬풀 방식을 적용 하여 선형성이 우수하고 $50 \mathrm{MHz} 870 \mathrm{MHz}$ 대역을 $34 \mathrm{~dB}$ 증폭하는 하이브리드형 $\mathrm{AMP}$ 를 적용하였고 위성대역에 증폭단 설계를 위해서는 $950 \mathrm{MHz} 2.15 \mathrm{GHz}$ 에서 $18 \mathrm{~dB}$ 를 증폭하는 $50 \mathrm{MHz} 6 \mathrm{GHz}$ 광대역 $\mathrm{MMIC}$ 증폭소자를 적용 하였다.

$\mathrm{AMP}$ 에서 발생되는 열을 방열하기 위해 $\mathrm{AMP}$ 와 $\mathrm{PCB}$ 사이에 방열판을 적용하여 방열효과를 극대화하고 $40 \mathrm{~dB}$ 이상의 높은 증폭도로 인해 발생되는 위성대역과 MATV 대역간의 간섭을 줄이기 위해 차폐 기구물이 요구된다. 이상의 기술들을 적용하여 개발되는 제품의 성능 목표는 다음과 같다.

[표 1] 통합형 증폭기 성능목표

\begin{tabular}{|c|c|c|c|c|}
\hline \multirow{2}{*}{\multicolumn{2}{|c|}{$\begin{array}{l}\text { 구 분 } \\
\text { 주파수대역 }\end{array}$}} & 단 위 & \multicolumn{2}{|c|}{ 목표치 } \\
\hline & & MHz & $54 \sim 806$ & $950 \sim 2150$ \\
\hline \multicolumn{2}{|c|}{ 최대이득 } & $\mathrm{dB}$ 이상 & 30 & 40 \\
\hline \multicolumn{2}{|c|}{ 대역내 이득편차 } & $\pm \mathrm{dB}$ 이내 & \pm 1 & \pm 2 \\
\hline \multicolumn{2}{|c|}{ 정격출력레벨 } & $\mathrm{dB} \mu \mathrm{V}$ 이상 & 105 & 110 \\
\hline \multicolumn{2}{|c|}{ 이득조정범위 } & $\mathrm{dB}$ 이상 & 20 & 10 \\
\hline \multicolumn{2}{|c|}{ 경사조정범위 } & $\mathrm{dB}$ 이상 & 15 & 15 \\
\hline \multicolumn{2}{|c|}{ 3차 상호변조(CTB) } & $\mathrm{dB}$ 이하 & -60 & - \\
\hline \multicolumn{2}{|c|}{ 2차 상호변조(CSO) } & $\mathrm{dB}$ 이하 & -60 & - \\
\hline \multicolumn{2}{|r|}{ 혼변조 } & $\mathrm{dB}$ 이하 & -55 & - \\
\hline \multicolumn{2}{|c|}{ 잡음지수 } & $\mathrm{dB}$ 이하 & 10 & 10 \\
\hline \multicolumn{2}{|r|}{ 험변조 } & $\mathrm{dB}$ 이하 & -63 & -63 \\
\hline \multicolumn{2}{|c|}{ 반사손실 } & $\mathrm{dB}$ 이상 & 14 & 8 \\
\hline \multicolumn{2}{|c|}{$\begin{array}{c}\text { 3차 } \\
\text { 상호변조왜곡(IMD3) }\end{array}$} & $\mathrm{dB}$ 이하 & - & -50 \\
\hline \multirow{3}{*}{$\begin{array}{l}\text { 누설 } \\
\text { 전자파 }\end{array}$} & $54 \mathrm{MHz}$ 이하 & $\mu \mathrm{V} / \mathrm{m}$ 이하 & 15 & 15 \\
\hline & $54 \sim 216 \mathrm{MHz}$ & $\mu \mathrm{V} / \mathrm{m}$ 이하 & 20 & 20 \\
\hline & $216_{\mathrm{MHz}}$ 이상 & $\mu \mathrm{N} / \mathrm{m}$ 이하 & 15 & 15 \\
\hline
\end{tabular}




\section{3. 연구 결과 및 분석}

개발된 제품은 외형적으로 크게 MATV 신호와 위성 신호를 입력받는 $75 \mathrm{ohm} \mathrm{RF} \mathrm{Connector와} \mathrm{증폭된} \mathrm{신호를}$ 출력하는 출력 $75 \mathrm{ohm} \mathrm{RF} \mathrm{Connector,} \mathrm{출력신호를} \mathrm{모니터}$ 할 수 있는 모니터용 $75 \mathrm{ohm} \mathrm{RF} \mathrm{Connector,} \mathrm{220VDC} \mathrm{전}$ 원을 공급하는 전원케이블과 전원상태 Monitor LED, MATV대역과 위성대역의 출력신호를 조절하는 이득조 정단자와 기울기를 조절할 수 있는 SLOPE 단자, 위성 $\mathrm{LNB}$ 의 전원을 공급하는 전원공급 스위치로 구성된다.

그림 13 은 반사손실을 측정한 결과로 (a)입력반사손실 과 (b)출력반사손실의 측정결과를 보면 MATV대역에서 $-14 \mathrm{~dB}$ 이하로 측정되었으며, 위성대역에서 $-10 \mathrm{~dB}$ 이하로 측정되었다. 따라서, 반사손실에 대한 개발 목표치인 $\mathrm{MATV}$ 에서 $-14 \mathrm{~dB}$ 이하 위성대역에서 $-8 \mathrm{~dB}$ 이하를 달성 하였다.
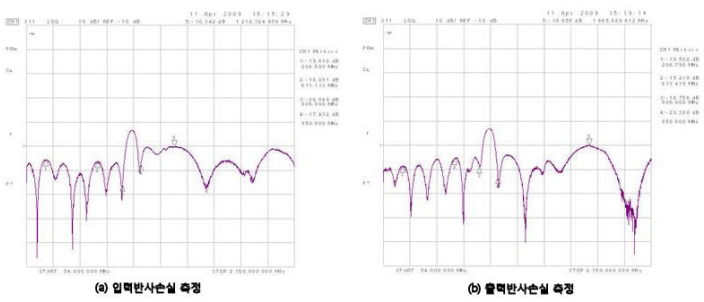

[그림 13] 반사손실 측정결과

그림 14 는 주파수응답 및 증폭도 특성을 측정한 결과 이다. 측정 결과를 보면, MATV 대역에 대하여 응답특성 이 $\pm 1 \mathrm{~dB}$ 이내이며, 증폭도가 $30 \mathrm{~dB}$ 이상으로 측정되었다. 또한, 위성대역에 대하여 응답특성이 $\pm 2 \mathrm{~dB}$ 이내고, 증폭 도가 $40 \mathrm{~dB}$ 이상으로 측정되어 주파수응답 및 증폭도에 대하여 목표치를 달성하였다.
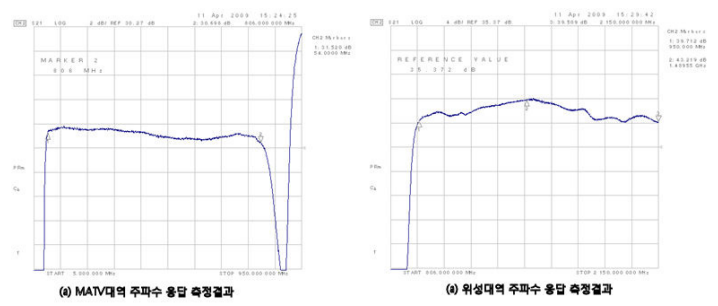

[그림 14] 주파수 응답 및 증폭도 측정결과

그림 15 는 조절형 광대역 RF 감쇠기를 이용한 이득조 정범위에 대한 측정결과이다. 측정결과를 보면 MATV대
역의 이득조정범위가 $20 \mathrm{~dB}$ 이상 측정되었으며, 위성대역 의 경우 $10 \mathrm{~dB}$ 이상 측정되어 목표치를 달성하였다.
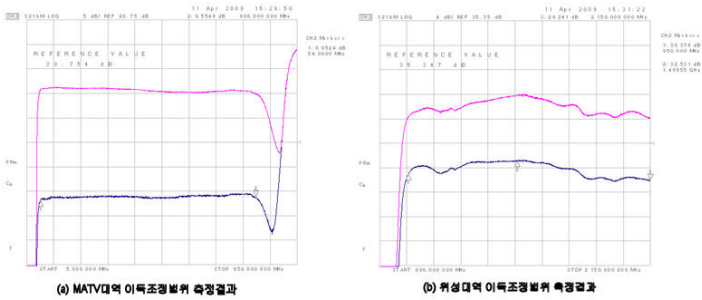

[그림 15] 이득조정범위 측정결과

그림 16은 Adjustable RF SLOPE 단자의 기울기 조정 범위에 대한 측정결과이다. 측정결과를 보면, MATV대역 의 기울기 조정범위가 $15 \mathrm{~dB}$ 이상이며 위성대역 경우에는 $15 \mathrm{~dB}$ 이상으로 나타났다. 따라서, 두 대역 모두 $15 \mathrm{~dB}$ 이 상으로 목표치를 달성하였다.

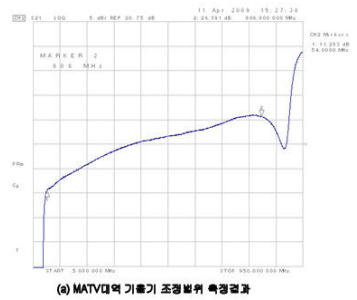

[그림 16] 기울기 조정범위 측정결과
그림 17은 MATV와 위성대역에 대한 RF 왜곡성능을 측정한 결과이다. MATV의 경우 멀티 신호 발생기를 이 용하여 IMD 왜곡성능을 측정하였다. 그림 17 의 (a)는 MATV대역에 입력 될 멀티신호 발생기의 77채널을 측정 한 결과로 입력될 77채널신호는 평탄하도록 하여 $15 \mathrm{dBmV} / \mathrm{ch}$ 로 설정하였다. (b)는 상기 멀티신호를 입력으 로 하여 증폭된 출력신호를 측정한 결과로 측정결과 $30 \mathrm{~dB}$ 증폭하여 $45 \mathrm{dBmV} / \mathrm{ch}$ 로 측정되었다. 상기 그림 17(b)의 출력신호에 대하여 RF 왜곡성능을 측정하였다. $\mathrm{RF}$ 왜곡성능 측정은 77 개의 채널 중에 14 번 채널 $(121.25 \mathrm{MHz})$ 과 77 번 채널 $(541.25 \mathrm{MHz})$ 을 선택하여 측정 하였는데 이는 낮은 채널과 높은 채널을 측정함으로서 신뢰성을 확보하기 위함이다.

그림 18은 MATV에 대한 RF 왜곡성능을 측정한 결과 로 $\mathrm{CSO}, \mathrm{CTB}, \mathrm{XMOD}, \mathrm{HUM}$ 변조를 순서대로 측정한 결 과이다. 측정된 결과를 보면, $\mathrm{CSO}$ 는 $74 \mathrm{~dB}$ 이상, $\mathrm{CTB}$ 는 $66 \mathrm{~dB}$ 이상, $\mathrm{XMOD}$ 는 $66 \mathrm{~dB}$ 이상, $\mathrm{HUM}$ 변조는 $77 \mathrm{~dB}$ 이상 으로 측정되었으며 이는 목표치보다 더욱 높은 결과이다. 


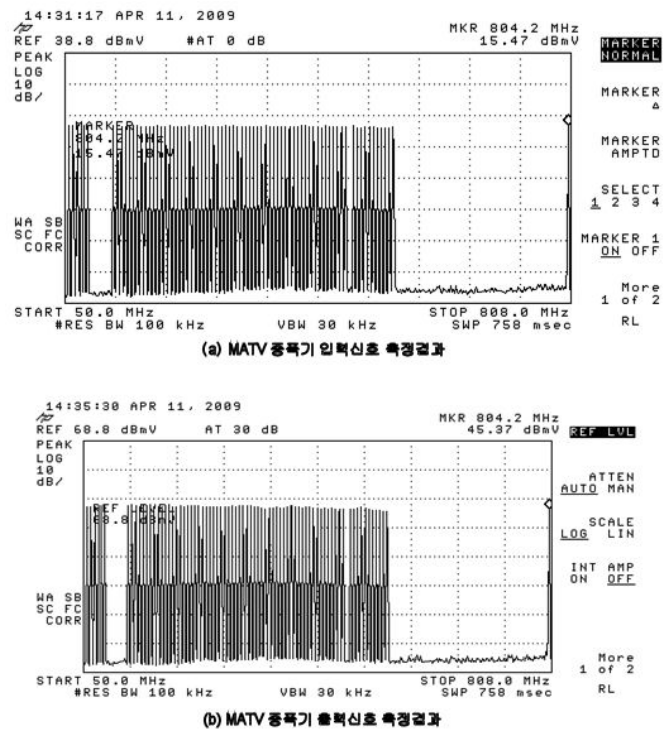

[그림 17] MATV 증폭기 입출력 신호 측정결과
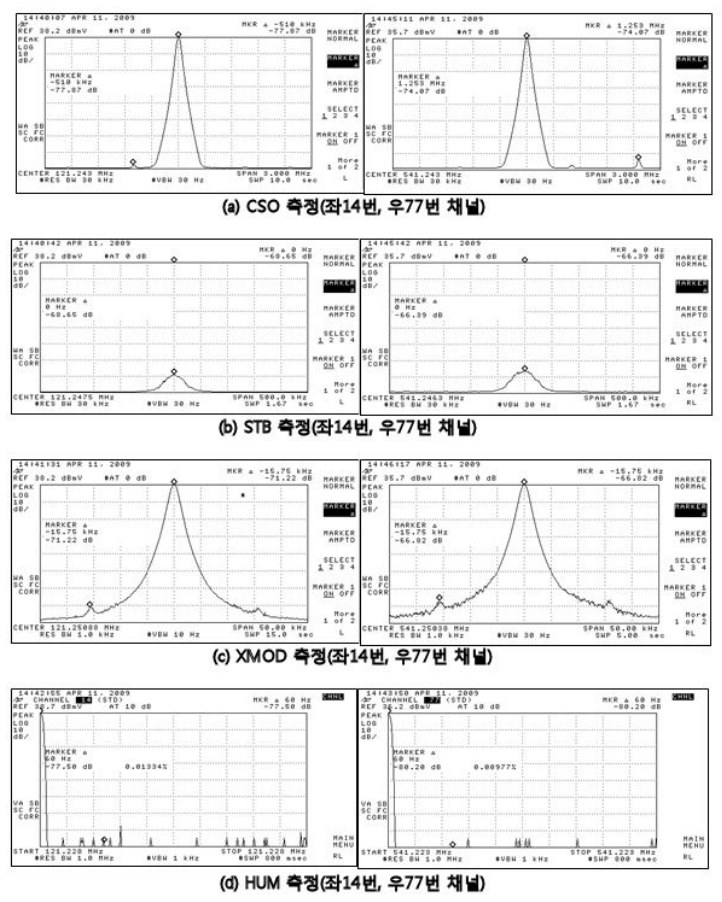

[그림 18] MATV RF 왜곡성능 측정결과

그림 19 는 위성대역의 2tone 시험을 위한 입출력신호 를 측정한 결과이다. 입력신호는 $6 \mathrm{MHz}$ 차이를 두어 $985.25 \mathrm{MHz}$ 와 $991.25 \mathrm{MHz}$ 를 선택하였으며, $10 \mathrm{dBmV} / \mathrm{ch}$ 레벨로 조정하여 입력하였다. 출력 측정결과는 $0 \mathrm{~dB}$ 증폭
되어 $50 \mathrm{dBmV}$ 로 측정되었다.

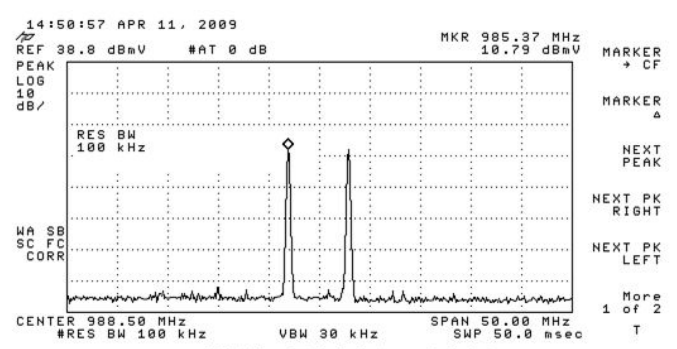

(a) 위성대역 중펵기 인혁 2tone 촉졍졀과

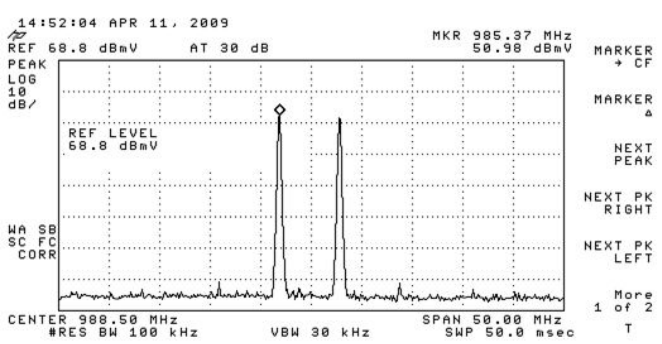

(b) 위성대역 중펵기 츨려 2 tone 측정결과

[그림 19] 위성대역 증폭기 입출력 2tone 측정결과

그림 20은 상기 측정된 출력신호에 대하여 IMD3를 측 정한 결과이다. 측정결과 $53 \mathrm{~dB}$ 이상으로 목표치보다 우 수한 결과가 나타났다.
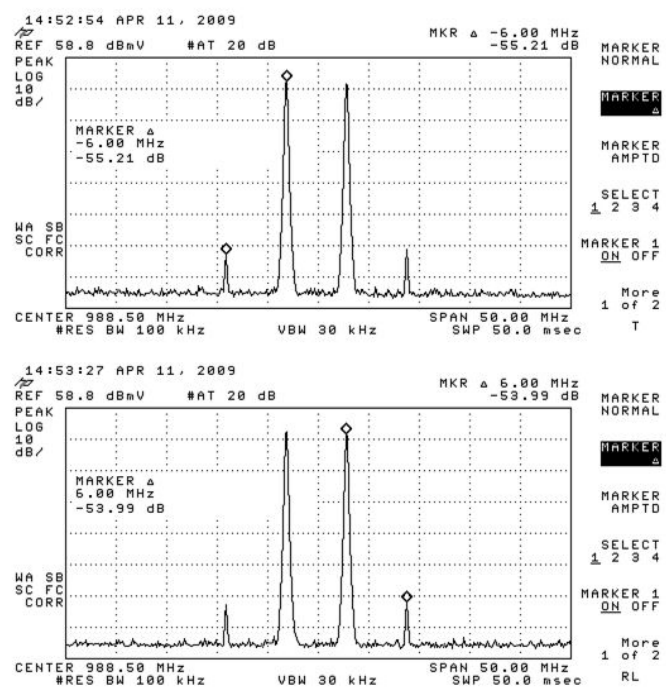

[그림 20] 위성대역 IMD3 측정

개발제품의 통합검증 내용을 초기 목표치와 비교하여 표 2 와 같다. 
[표 2] 개발 제품의 통합검증 데이터

\begin{tabular}{|c|c|c|c|c|c|c|}
\hline \multirow{2}{*}{$\begin{array}{l}\text { 평가 } \\
\text { 항목 }\end{array}$} & \multirow[t]{2}{*}{ 단위 } & \multicolumn{2}{|c|}{$\begin{array}{c}\text { 개발 } \\
\text { 목표치 }\end{array}$} & \multicolumn{2}{|c|}{$\begin{array}{l}\text { 시제품 } \\
\text { 성능 }\end{array}$} & \multirow{2}{*}{$\begin{array}{c}\text { 기 타 } \\
\text { (측정대역) }\end{array}$} \\
\hline & & MATV & 위성 & MATV & 위성 & \\
\hline $\begin{array}{l}\text { 출력 } \\
\text { 이득 }\end{array}$ & $\mathrm{dB}$ & 30 & 40 & 30 & 40 & $\begin{array}{l}\text { MATV 및 } \\
\text { 위성 }\end{array}$ \\
\hline IMD3 & $\mathrm{dB}$ & - & 50 & - & 53 & 위성 \\
\hline $\mathrm{CSO}$ & $\mathrm{dB}$ & 60 & - & 74 & - & MATV \\
\hline CTB & $\mathrm{dB}$ & 60 & - & 66 & - & MATV \\
\hline $\begin{array}{l}\text { 주파수 } \\
\text { 평탄도 }\end{array}$ & $\mathrm{dB}$ & 2 & 4 & 2 & 4 & $\begin{array}{l}\text { MATV 및 } \\
\text { 위성 }\end{array}$ \\
\hline $\begin{array}{l}\text { 경사 } \\
\text { 조정 }\end{array}$ & $\mathrm{dB}$ & 15 & 15 & 15 & 15 & $\begin{array}{l}\text { MATV 및 } \\
\text { 위성 }\end{array}$ \\
\hline
\end{tabular}

\section{4. 결론}

본 연구에서는 방송통신 융합 기술의 일환으로 SMATV 설비기준에 부합되면서 MATV 및 위성방속 대 역이 전송 가능한 증폭기 개발과 그에 따른 핵심 기술을 제안하였다. 특히, 본 연구에서 제안된 증폭기는 공동주 택의 각 세대까지 연결된 동축선로를 통하여 $\operatorname{MATV}(54$ $\sim 806 \mathrm{MHz})$ 와 위성방송 $(950 \mathrm{MHz} \sim 2150 \mathrm{MHz})$ 을 동시에 입력이 가능한 특징을 가지고 있다. 그러나 이와 같은 증 폭기 방식은 방송 서비스별로 변조방식이 상이하기 때문 에 서비스 대역을 제외한 대역에 예상치 못한 노이즈가 발생하게 되고 이는 방송 품질을 저해하는 원인이 된다. 또한, 증폭기는 신호뿐만 아니라 노이즈도 증폭되기 때문 에 이로 인한 간섭 또한 커지게 된는 문제점이 있다. 따 라서, 본 연구에서는 이와 같은 문제점의 해결방안으로 대역간의 간섭을 억제하는 필터(Filter)를 제안하고, 동축 케이블에서 발생되는 전송손실이 주파수 대역에 따라 차 이가 발생하는 문제점을 해결하기 위해 MATV와 위성대 역용 등화기(Equalizer)를 제안하였다.

본 연구에서 제안된 통합형 증폭기는 MATV에서 구 내용 증폭기 부분만을 변경함으로써 추가 설치에 따른 설치공간의 제약과 설비비용을 절감하는 동시에 각 세대 별로 위성 안테나를 각각 설치해야하는 문제점을 해결하 고 위성수신이 어려운 사각지역을 제거할 수 있다.

향후 연구과제로는 본 연구가 기술의 융합화에 따른 통신과 방송을 효율적으로 서비스할 수 있는 기반 기술 이므로 광대역의 인프라 구축에 따른 화면/고화질 VOD 서비스, $3 \mathrm{D}$ 의료영상 정보 서비스, $3 \mathrm{D}$ 게임 등에 적용할 수 있도록 비디오 광수신기와의 통합과 점차 확대되고 있는 무선전송 기술이 요구된다.

\section{참고문헌}

[1] 텔레비전공동시청안테나시설등의설치기준에관한규칙, 정통부, 2007년 11월

[2] 이병섭, “종합유선방송과 위성방송의 관계정립방안", 한국방송학회, 통권 제 57 호, 2003.12, p.52-54

[3] Nonoru Ishihaea et al., "Low-Voltage, Adjustment free Analog Critical and Low-Power Logic LSI Technologies for Optical Network Termination Unit", NTT REVIEW, Vol.9, No.6, Nov. 1997, pp. 86-94.

[4] 이진영, 김보남, "이중 대역 방송 서비스가 가능한 비디오 광수신기(ONU: Optical Network Unit)의 개 발",한국해양정보통신학회제13권 11호, 2009.11, p. 2413

[5] 민월기, "디지털방송 환경 개선을 위한 위성방송 수 신 방식별 경제성 연구", 학윈논문(석사), 충주대학교 산업대학원, 전자통신공학과, 2009.2.

[6] 이상식, "디지털 다채널 시대의 케이블 TV 주요 현 안과 과제", 한국언론정보학회 학술대회, 2007.12, pp. 98-99

\section{이 진 영(Jin-Young Lee)}

[정회원]

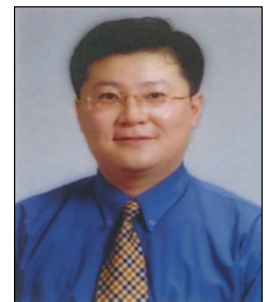

- 1995년 2월 : 단국대학교 단국대 학원 전산통계학과 (이학석사)

- 1998년 2월 : 단국대학교 단국대 학원 전산통계학과 (이학박사수 료)

- 1999년 9월 현재 : 강남대학 교 교양학부 부교수

<관심분야>

소프트웨어공학, 생체인식, 방송통신융합 